Check for updates

Cite this: RSC Adv., 2019, 9, 35304

Received 26th August 2019

Accepted 3rd October 2019

DOI: $10.1039 / c 9 r a 06726 d$

rsc.li/rsc-advances

\section{Bioremediation of petroleum hydrocarbon- contaminated soil by petroleum-degrading bacteria immobilized on biochar}

\begin{abstract}
Bofan Zhang, $\mathbb{D} \dagger$ Liang Zhang† and Xiuxia Zhang $\dagger^{*}$
Biochar is investigated experimentally as a new highly effective amendment to remediate contaminated soil. A crucial consideration is the influence of biochar on the bioremediation of soil polluted with total petroleum hydrocarbons (TPHs), and in particular, the use of biochar as a bacteria immobilization carrier with a synergistic effect of absorption and degradation. Therefore, we studied the ability of petroleumdegrading bacteria immobilized on biochar, free bacteria, and biochar alone on the removal of TPHs in soil using gravimetric analysis and gas chromatography-mass spectrometry. After 60 days of remediation, the strategy involving immobilized bacteria on biochar was more effective than other treatments in reducing the contents of TPHs and $n$-alkanes with $\mathrm{C}_{12-18}$, which showed the shortest halflife and highest biodegradation efficiency; variations in the features of enzymatic activities and microbial respiration indicated that the biochar treatment improved not only the soil fertilizer and carbon storage, but the immobilization greatly affected both the physicochemical properties of soil and bacterial activities. Moreover, the bacterial population diversity and bioavailability of hydrocarbons were promoted by the inputs of the combination of biochar and petroleum-degrading bacteria. Overall, our results highlight the potential of applying immobilized microorganisms on biochar for accelerating the biodegradation of petroleum and maintaining the balance of the soil ecosystem, which may be ascribed to the synergistic effect of biostimulation and bioaugmentation.
\end{abstract}

\section{Introduction}

Soil contamination with total petroleum hydrocarbons has emerged as a serious environmental and human health concern with a large percentage of used oil discharged into the ecosystem without any treatment. ${ }^{\mathbf{1}}$ Petroleum hydrocarbons are composed of carbon, oxygen, hydrogen, nitrogen and sulfur. Saturated hydrocarbons, aromatic hydrocarbons, colloid and asphaltene are the four large TPH fractions that are toxic and cannot be quickly degraded by soil microorganisms. ${ }^{2}$ Furthermore, weathering could enhance the sorption of contaminants into soil pores, leading to chronic soil aging problems and decreased bioavailability and biodegradability of biota to pollutants. ${ }^{3,4}$ Soil contaminated with petroleum hydrocarbons is a huge ecological problem, and there is an urgent need to find effective approaches for the remediation of soil.

Bioremediation technologies are finding wider and wider applications when compared with physical and chemical remediation methods owing to their high efficiency, low cost and harmless products (mainly $\mathrm{CO}_{2}$ and water). ${ }^{5}$ The critical factors in bioremediation are microbial quantity and activity,

College of Chemical Engineering, China University of Petroleum (East China), Qingdao 266580, China.E-mail: zhxiuxia@upc.edu.cn

$\dagger$ These authors contribute equally to this work. soil nutrients and oxygen status. However, petroleumcontaminated soil usually has a low number of microbes, low porosity and nutrients, limiting the degradation efficiency of microorganisms in practical application. ${ }^{6-8}$ The bioaugmentation method is implemented by introducing hydrocarbon-degrading bacteria, ${ }^{9}$ whereas the biostimulation method employs the addition of nutrients and carbon sources to increase the activities of indigenous microbes. The combined technologies of bioaugmentation and biostimulation not only can introduce active bacteria but can also stimulate indigenous microorganisms and ameliorate the character of soil.

The number and activities of the introduced free bacteria might be inhibited by the toxicity of petroleum hydrocarbons, alkaline or acidic pH, lack of nutrients and competitive action with indigenous microorganisms. To improve the bacterial density and competitive advantage of exogenous bacteria, an effective method is to immobilize the hydrocarbon-degrading bacteria on a protective carrier material, which can provide a suitable habitat for the microbes and help them resist the harsh soil conditions. Numerous current studies indicate that agricultural wastes can be used to immobilize carrier materials such as rice straw, peanut shell and biochar. ${ }^{\mathbf{1 0 , 1 1}}$ These materials have good capacity to transmit oxygen, hold water and improve the enzymatic activities. ${ }^{12}$ Compared with raw agricultural wastes, biochar has high carbon content, high adsorption 
capacity, good stability, and optimal immobilization ability for bacteria and nutrients.

Spent mushroom substrate biochar is the product of a spent mushroom substrate produced through pyrolysis under low or zero oxygen conditions at $200-700{ }^{\circ} \mathrm{C} .{ }^{4,13}$ The type of feedstock materials and production conditions (pyrolysis temperature, heating rate and residence time) can directly affect the physicochemical properties and overall suitability of a carrier; ${ }^{14-16}$ biochar has been reported to have a positive impact on soil fertility, carbon sequestration and the activities of specific enzymes such as dehydrogenase, polyphenol oxidase and FDA hydrolase. ${ }^{13,17}$ A number of lignin and cellulose biochars can also serve as substrates for the growth and reproduction of microorganisms. Moreover, the large specific surface area, welldeveloped porous structure and rich superficial functional group of biochar ${ }^{18}$ may therefore enhance the adsorption capacity of bacteria and the effect of contaminants. Hence, the combination of the amendment of biochar with bacteria may be an excellent approach to remove TPHs and improve the polluted soil condition.

Although numerous studies have reported the impact of bacteria on the remediation of contaminated soil individually, ${ }^{19}$ only few studies have reported the influence of biochar combined with microorganisms via immobilization on the bioremediation effect of TPH-polluted soil. Further investigation of this study on the preparation of degrading bacteria immobilized on biochar and the combined effect of removal efficiency of TPHs by immobilized bacteria during the remediation process. Accordingly, the biochar and petroleumdegrading bacteria were studied in different combinations for a continuous interval monitoring, including immobilized, free bacteria-biochar, biochar alone and bacteria alone treatments. Additionally, soil physicochemical properties, enzymatic activity and microbial community were also investigated to elucidate the effects of biostimulation and bioaugmentation.

\section{Materials and methods}

\subsection{Soil and biochar samples}

The petroleum hydrocarbon-contaminated soil used in this study was collected from around $20 \mathrm{~cm}$ depth of Shengli Oilfield, China. The soil samples were homogenized, air-dried at room temperature and sieved by a $2 \mathrm{~mm}$-sieve in order to remove large impurities, and then stored at $-40{ }^{\circ} \mathrm{C}$ in the dark for later use.

Biochar was produced by a tube furnace under limited oxygen in a controlled atmosphere furnace. A spent mushroom substrate (SMS) gathered from Tiannong Edible Fungus Co., Ltd, located in Qingdao, China was used as the raw material. The SMS was washed by deionized water and dried in the oven at $75{ }^{\circ} \mathrm{C}$ for $24 \mathrm{~h}$. Subsequently, the material was chopped into $1-2 \mathrm{~cm}$ long pieces, and pyrolyzed at $550^{\circ} \mathrm{C}$ for $3 \mathrm{~h}$ at a heating rate of $10{ }^{\circ} \mathrm{C} \mathrm{min}^{-1}$. Finally, the pyrolyzed sample denoted as BC550 was washed with deionized water until its $\mathrm{pH}$ became stable and then passed through a 40 mesh sieve for further use. ${ }^{20}$ The soil and biochar $\mathrm{pH}$ were measured by a $\mathrm{pH}$ meter (NY/T 1377-2007, China), the electrical conductivity (EC) was tested with a conductivity meter ${ }^{21}$ and the organic matter (OM) was determined by the potassium dichromate volumetric method (GB 9834-1988, China). The basic physicochemical properties of the soil and biochar are presented in Table 1 and the $\mathrm{pH}, \mathrm{EC}$ and $\mathrm{OM}$ of the soil after the bioremediation are given in Fig. 1.

\subsection{Bacteria immobilization}

The strains of petroleum-degrading bacteria with highefficiency decomposition were separated from the abovementioned TPHs-contaminated soil. The screened strain used for immobilization was named H3. H3 is identified as Microbacterium by the identification method of configuration, physiology, biochemistry, and molecular biology. In addition, the biodegradable ratio of TPHs reached $54.31 \%$ after 15 days. Before immobilization, $2 \mathrm{~mL}$ liquid bacterial germ was added to sterilized Erlenmeyer flasks with LB liquid medium and cultivated on a rotary shaker at $30{ }^{\circ} \mathrm{C}$ and $160 \mathrm{rpm}$. Cells were harvested by centrifugation for $10 \mathrm{~min}$ at $5000 \mathrm{rpm}$ and washed three times with sodium chloride saline.

The BC550 sample was placed into a flask and sterilized at $121{ }^{\circ} \mathrm{C}$ for $20 \mathrm{~min}$. After cooling to room temperature, the $\mathrm{H} 3$ cells were mixed with $5 \mathrm{~g}$ of BC550 in a shaker at $160 \mathrm{rpm}$ for $24 \mathrm{~h}$ to sufficiently absorb the bacteria by BC550. After that, the immobilized hydrocarbon-degrading bacteria were dried by vacuum freeze-drying (SJIA-10N-50A) and stored at $4{ }^{\circ} \mathrm{C}$. The immobilized bacteria and BC550 can be observed by scanning electron microscopy ${ }^{22}$ (SEM, Hitachi® S-4800 scanning microscope, Japan) respectively to confirm whether the bacteria were loaded on biochar.

\subsection{Remediation of TPHs-contaminated soil}

All treatments were carried out in flowerpot reactors filled with $500 \mathrm{~g}$ unsterilized contaminated soil. For each treatment, $\left(\mathrm{NH}_{4}\right)_{2} \mathrm{SO}_{4}$ and $\mathrm{KH}_{2} \mathrm{PO}_{4}$ at a carbon-nitrogen-phosphorous $(\mathrm{C}: \mathrm{N}: \mathrm{P})$ ratio of $100: 10: 1$ were amended, which is considered the optimal dosage for soil bioremediation. ${ }^{23}$ The treatments were as follows: (1) the soil without the biochar and bacteria addition was used as the control (CK); (2) the bacteria was amended at a $10 \% \mathrm{v} / \mathrm{w}$ ratio to the soil to assess the

Table 1 Physicochemical properties of soil and biochar

\begin{tabular}{llc}
\hline Properties & Soil & Biochar \\
\hline $\mathrm{pH}$ & 7.39 & 11.3 \\
Organic matter $\left(\mathrm{g} \mathrm{kg}^{-1}\right)$ & 9.85 & 33.5 \\
Total nitrogen $\left(\mathrm{g} \mathrm{kg}^{-1}\right)$ & 0.0470 & 15.7 \\
Available phosphorus $\left(\mathrm{g} \mathrm{kg}^{-1}\right)$ & 0.0121 & 0.440 \\
Electrical conductivity $\left(\mathrm{mS} \mathrm{cm}^{-1}\right)$ & 1.45 & 6.13 \\
Ash $(\%)$ & - & 32.6 \\
$\mathrm{H} / \mathrm{C}$ & - & 0.320 \\
BET $\left(\mathrm{m}^{2} \mathrm{~g}^{-1}\right)$ & - & 109.3 \\
Pore volume $\left(\mathrm{cm}^{3} \mathrm{~g}^{-1}\right)$ & - & 0.103 \\
Average pore size $(\mathrm{nm})$ & - & 13.1 \\
TPHs $(\%)$ & 4.77 & -
\end{tabular}



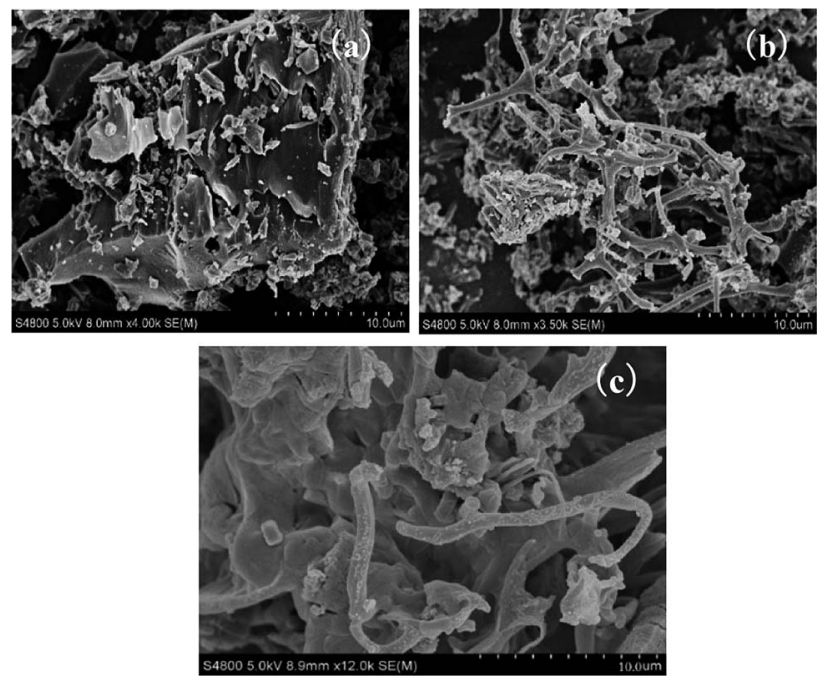

Fig. 1 Scanning electron microscopy (SEM) images of (a) a spent mushroom substrate (SMS); (b) biochar (BC550); and (c) immobilized bacteria on the surface of BC550.

biostimulatory effect of the bacteria alone (BF); (3) the sterilized biochar was amended at a $5 \% \mathrm{w} / \mathrm{w}$ ratio to the soil to assess the bioaugmentation effect of the biochar alone (BC); (4) the sterilized biochar was added in a $5 \% \mathrm{w} / \mathrm{w}$ ratio, while the bacteria was applied in a $10 \% \mathrm{v} / \mathrm{w}$ ratio in soil to assess the effect of biocharfree degrading bacteria (BMF); (5) the immobilized microorganisms were mixed with soil in a $5 \% \mathrm{w} / \mathrm{w}$ ratio to assess the combined effect of biochar and degrading bacteria (BIM).

Five treatments were carried out in three replicates and incubated at $30{ }^{\circ} \mathrm{C}, 60 \%$ relative humidity (RH) for 60 days. Deionized water was added every two days to keep the moisture content at $70 \%$ of the maximum water holding capacity, and the indexes of soil physiochemical properties, enzyme activities and microbe quantity were measured every 10 days.

\subsection{Total petroleum hydrocarbons of soil analysis}

After the incubation experiment, the soil samples were freezedried, extracted and analysed. TPHs extracted from the soil were determined using the gravimetric method. In brief, $5 \mathrm{~g}$ soil wrapped in filter paper were extracted using $30 \mathrm{~mL}$ of methylene chloride by ultrasonication for $15 \mathrm{~min}$, and then the paper was transferred into the Soxhlet extractor at $54{ }^{\circ} \mathrm{C}$ water bath for $12 \mathrm{~h}$. After that, the extracts were concentrated on a rotary evaporator, and then made up to a constant volume of $50 \mathrm{~mL}$ for measurement. The amount of residual TPHs were quantified on gravimetrically and the concentration of $n$-alkanes $\left(\mathrm{C}_{12-18}\right)$ was measured by a gas chromatograph mass spectrometer (GC-MS, model 7890-5975C, Agilent Technologies, USA). The TPHs removal (\%) was calculated using the followed formula:

$$
\text { TPHs removal }(\%)=\left[\left(w_{0}-w_{t}\right) / w_{0}\right] \times 100
$$

where $w_{0}$ is the initial soil TPHs concentration $\left(\mathrm{g} \mathrm{kg}^{-1}\right), w_{t}$ stands for the residual TPHs concentration at time $t\left(\mathrm{~g} \mathrm{~kg}^{-1}\right)$, and $t$ is the remediation time (day).

\subsection{Soil enzymatic activities analysis}

Dehydrogenase, FDA hydrolysis, polyphenol oxidase activities were measured by an ultraviolet spectrophotometer (PERSEE TU-1901). Dehydrogenase activity was tested by incubating $1 \mathrm{~g}$ soil with $1 \mathrm{~mL}$ of triphenyltetrazolium chloride (TTC) for $6 \mathrm{~h}$ at $30^{\circ} \mathrm{C}$. The formation of triphenylformazone (TPF) was analysed spectrophotometrically at $485 \mathrm{~nm}$. FDA hydrolysis activity was quantified by the addition of $10 \mathrm{~mL} 100 \mathrm{mmol} \mathrm{L}^{-1}$ potassium phosphate buffer (pH 7.0) and $0.2 \mathrm{~mL} 1 \mathrm{mg} \mathrm{mL}^{-1}$ FDA solution in a conical flask with $1 \mathrm{~g}$ soil. The reaction mixture was incubated at $30{ }^{\circ} \mathrm{C}$ for $1 \mathrm{~h}$, and fluorescein was extracted using a mixture of chloroform/methanol $(2: 1 \mathrm{v}: \mathrm{v})$. The extracted fluorescein was determined spectrophotometrically at $490 \mathrm{~nm}$. Polyphenol oxidase activity was measured using the colorimetric method with pyrogallol. The supernatant absorbance was detected spectrophotometrically at $430 \mathrm{~nm} \cdot{ }^{24,25}$ All samples were prepared in triplicate.

\subsection{Soil microbial respiration rate and bacteria diversity analysis}

The soil microbial respiration rate was measured by the alkali absorption method. ${ }^{26}$ The amount of $\mathrm{CO}_{2}$ released by the soil microorganism was calculated by the consumption of $\mathrm{HCl}$. The plate counting method was used to analyse the hydrocarbondegrading bacteria diversity and the details of the procedure are as follows:

$5 \mathrm{~g}$ of soil sample was dispersed in $100 \mathrm{~mL}$ sterile distilled water and fully shacked. Then, the solution was serially diluted and $0.2 \mathrm{~mL}$ of diluted aqueous solution was uniformly spread on the medium surface. The hydrocarbon-degrading bacteria was incubated with mineral salt medium containing $50 \mathrm{mg} \mathrm{L}^{-1}$ crude oil as the sole carbon source. After 5 days, the colonies capable of growing on the TPHs-containing MSM were counted as petroleum-degrading bacteria. ${ }^{27}$

\section{Results and discussion}

\subsection{Characterization of soil, biochar and immobilized bacteria}

The soil properties (Table 1) indicated that the concentration of TPHs was $47.7 \mathrm{~g} \mathrm{~kg}^{-1}$, with $49.87 \%$ saturated hydrocarbons, $26.02 \%$ aromatic hydrocarbons, $17.88 \%$ colloid, and $5.63 \%$ asphalt. The contaminated soil had a near-neutral pH (7.39), and the concentration of organic matter, total nitrogen and available phosphorus reached 9.85, 0.047 , and $0.0121 \mathrm{~g} \mathrm{~kg}^{-1}$, respectively, indicating that soil nutrition were deficient and imbalanced. The abundance of organic matter, total nitrogen and available phosphorus in biochar were 33.5, 15.7 and $0.440 \mathrm{~g}$ $\mathrm{kg}^{-1}$ higher than soil. The BET surface area value of the biochar was $109.27 \mathrm{~m}^{2} \mathrm{~g}^{-1}$, which was 21.7 folds larger than that of the raw material $\left(5.04 \mathrm{~m}^{2} \mathrm{~g}^{-1}\right)$. The pore volume and average pore size were $0.103 \mathrm{~cm}^{3} \mathrm{~g}^{-1}$ and $13.09 \mathrm{~nm}$ separately. The large surface area and pore volume, and small pore-size are favourable for the adsorption of bacteria and pollutants.

The SEM images of the spent mushroom substrate (SMS), biochar (BC550) and immobilized bacteria with biochar are 
illustrated in Fig. 1. BC550 (Fig. 1b) presented a skeleton structure and richer pore number than SMS (Fig. 1a). Bacillar hydrocarbon-degrading bacteria was successfully attached to the surface of biochar (Fig. 1c). The skeleton structure and microporous property of the carbon materials can provide an appropriate living space for bacteria, and the abundant alkaline functional groups on the biochar surface can weaken the hydrophobic interaction with cells and form a strong joint between the bacteria and carrier. ${ }^{28}$

\subsection{Biodegradation of petroleum hydrocarbons}

TPHs in soil samples collected from the five treatments were detected after 60 days. As shown in Fig. 2f, the TPHs removal quantities were $3.98,26.85,20.74,17.68$ and $13.66 \mathrm{~g} \mathrm{~kg}^{-1}$ in the control, BIM, BMF, BF and BC treatments, separately. The application of immobilized bacteria to the soil resulted in the largest TPHs decrease, followed by the biochar-free bacteria treatment. The main reason for such high efficiency in immobilized group is possibly due to the fact that immobilized bacteria are more adaptable to the contaminated soil than free bacteria and then microbial activity was promoted in a short time. ${ }^{29}$ Furthermore, the final TPHs content was $10.14 \%$ higher in $\mathrm{BF}$ than in $\mathrm{BC}$ and $22.30,12.16 \%$ in $\mathrm{BF}, \mathrm{BC}$ higher than that of the control (Fig. 2f). This may be due to the fact that the introduced free exogenous degrading bacteria and biochar both could improve the biodegradation of petroleum hydrocarbon in bioaugmentation and biostimulation patterns, respectively. However, the petroleum-degrading bacteria gives better results than biochar alone during 60 days incubation, suggesting that the degrading bacteria could adapt to soil environment quickly and have a higher ability of petroleum degradation than biochar..$^{6,30}$

The relative abundance of $n$-alkanes $\left(\mathrm{C}_{12-18}\right)$ of oil is presented in Fig. 2a-e. The $n$-alkanes with carbon chains $\mathrm{C}_{12-18}$ were decreased in all treatments in different degrees compared to the CK sample. The residual concentration of the chain $\left(\mathrm{C}_{12-15}\right)$ alkanes in the treatment with the petroleum-degrading bacteria was higher than that in treatments with biochar alone, and they were higher than that in the CK sample, indicating that shorter chain alkanes can be easily degraded by the introduced of bacteria. There is a non-obvious difference in the concentration of $\mathrm{C}_{16-18}$ observed between $\mathrm{BC}$ and $\mathrm{BMF}$, and an obvious difference between the $\mathrm{BF}$ and $\mathrm{BC}$ treatment, which could be related to the strong aromaticity and $\pi$-electron of the biochar pyrolyzed at high temperature. In addition, it also can form $\pi-\pi$ electronic interaction with hydrocarbons, ${ }^{31-33}$ making the adsorption effect of pollutants more stable and irreversible. ${ }^{34}$ More importantly, the abundance of $n$-alkanes $\left(\mathrm{C}_{12-}\right.$ ${ }_{18}$ ) in BIM was reduced at the largest level, which showed good accordance with the degradation efficiency of TPHs, implying that the immobilized microorganisms could utilize the carbon chain more widely than free bacteria. This probably means that the large specific surface area and rough surface structure of biochar are more conducive to attaching biofilms secreted by microorganisms, thus (a)

(b)

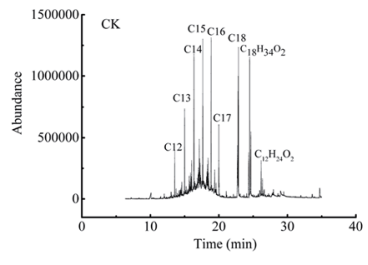

(c)

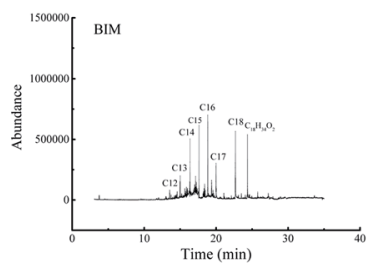

(d)

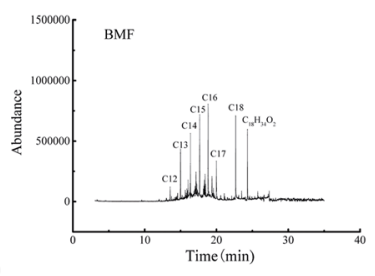

(e)

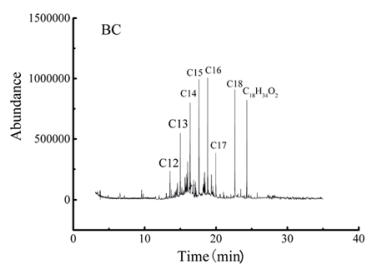

(f)
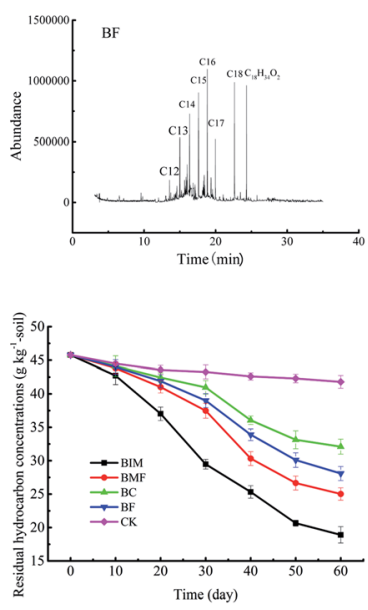

(g)

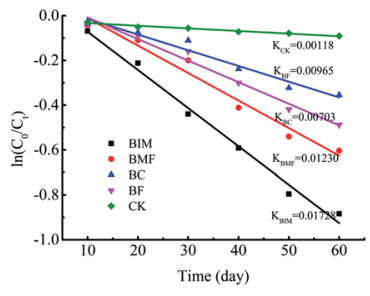

Fig. 2 (a-e) $n$-alkanes after 60 d remediation; ( $f$ ) residual hydrocarbon concentration of TPHs with remediation time; and $(\mathrm{g})$ the degradation kinetics equation of TPHs in five different treatments.

forming covalent bonds and specific adsorption between biochar and bacteria to improve the adsorption and degradation rate of hydrocarbon. 
The first-order kinetic model can further elucidate the biodegradation mechanism of biochar combined with bacteria. ${ }^{35}$ It can be calculated using the following formula:

$$
\ln C_{0} / C_{t}=k t
$$

where $C_{0}$ is the initial TPH concentration in soil $\left(\mathrm{g} \mathrm{kg}^{-1}\right), C_{t}$ is the residual TPHs concentration at time $t\left(\mathrm{~g} \mathrm{~kg}^{-1}\right), t$ is the time (day), and $k$ is the first-order constant of biodegradation $\left(d^{-1}\right)$.

Fig. $2 \mathrm{~g}$ demonstrates that the TPHs in the BIM microcosm had the shortest half-life (40.06 d) and highest biodegradation rate constant $\left(0.0173 \mathrm{~d}^{-1}\right)$, which were 1.41, 1.78, 2.47, 14.4-fold higher than BMF, BF, BC and CK treatments, respectively. The results revealed that the biochar amendments could enhance the dissipation of petroleum hydrocarbons from the soil and the structure of biochar might absorb more pollutants and make a more suitable habitat for immobilized degrading bacteria to achieve the interaction of adsorption and degradation. $^{36}$

\subsection{Soil pH, electrical conductivity and organic matter}

The changes in the soil $\mathrm{pH}$, electrical conductivity and organic matter before and after remediation were tested statistically (Table 2). Soil pH, organic matter and electrical conductivity reached the maximum values and were $8.81,2.42 \mathrm{mS} \mathrm{cm}^{-1}$ and $10.47 \mathrm{~g} \mathrm{~kg}^{-1}$ in BC treatment after $60 \mathrm{~d}$ of the experiment, respectively, while the three indicators decreased most when adding degrading bacteria alone. This is due to the accumulation of organic acids produced during the degradation of hydrocarbons under the action of enzymes, ${ }^{37}$ and the degradation of macromolecular substances in soil pollutants by microorganisms into small molecular substances (such as $\mathrm{CO}_{2}$ and $\mathrm{H}_{2} \mathrm{O}$ ), resulting in the decrease of the soil $\mathrm{pH}$ value. The continuous consumption of nutrients by microbial metabolism caused the organic matter content to decrease significantly in the later stage. However, no significant changes of soil $\mathrm{pH}$ and organic matter content were observed in the biochar alone treatment during all periods of remediation, which were ascribed to its characteristics of alkalinity, good resistance to harmful substances (such as organic acids), ${ }^{38}$ and buffer capacity for soil environmental change. Furthermore, biochar is rich in organic carbon, porosity and CEC, which not only can capture hydrocarbons, but also maintain the balance of the soil

Table 2 Variation of soil $\mathrm{pH}$, electrical conductivity and organic matter

\begin{tabular}{llll}
\hline Treatment & $\mathrm{pH}$ & $\begin{array}{l}\text { Electrical conductivity } \\
\left(\mathrm{mS} \mathrm{cm}^{-1}\right)\end{array}$ & $\begin{array}{l}\text { Organic matter } \\
\left(\mathrm{g} \mathrm{kg}^{-1}\right)\end{array}$ \\
\hline Before remediation & 7.39 & 1.45 & 9.85 \\
BIM & 7.76 & 1.62 & 5.98 \\
BMF & 7.83 & 1.55 & 7.99 \\
BF & 6.52 & 1.23 & 4.02 \\
BC & 9.31 & 2.42 & 10.47 \\
CK & 7.28 & 1.36 & 9.43
\end{tabular}

ecosystem for microorganisms, which could be as a promising carrier to immobilize bacteria in removing TPHs.

\subsection{Enzymatic activity}

Basic enzymatic activities, including dehydrogenase, FDA hydrolysis and polyphenol oxidase activity, were measured every 10 days and the results are shown in Fig. 3. Various studies have reported that the soil enzymatic activity is positively correlated with the microbial biomass and the soil fertility, ${ }^{39}$ which is a sensitive indicator of soil health and quality. The activities of the three enzymes gradually increased initially and then decreased slightly in the later remediation stage, whereas the change of the control treatment was not obvious. Such a variation indicated that the addition of biochar and bacteria can provide a new carbon source for the indigenous microorganisms, and

(a)

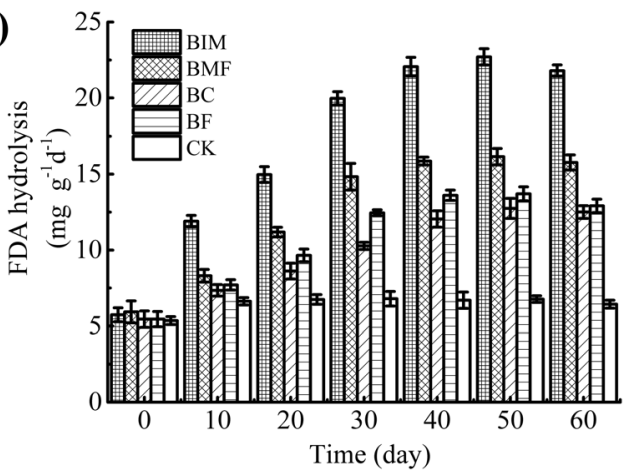

(b)

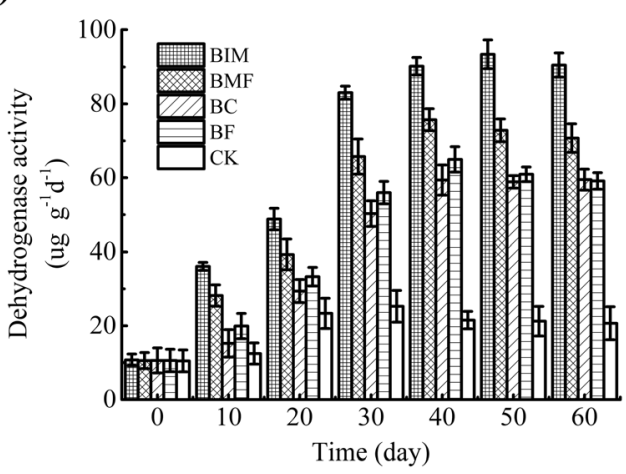

(c)

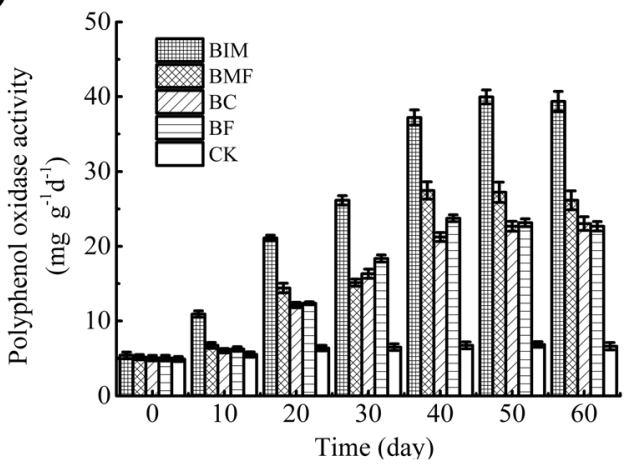

Fig. 3 Variation of the soil enzymatic activities of five treatments with remediation time. (a) FDA hydrolysis; (b) dehydrogenase; and (c) polyphenol oxidase activities. 
also increase the number and metabolic activity of microorganisms in soil. The immobilized bacteria on the biochar treatment (BIM) was maintained at the highest level during the entire remediation compared with $\mathrm{BMF}, \mathrm{BF}$ and $\mathrm{BC}$. At 50 days, the FDA hydrolysis, dehydrogenase and polyphenol oxidase activity in the immobilized bacteria on biochar treatment (BIM) reached maximum values and were $22.71 \mathrm{mg} \mathrm{g}^{-1} \mathrm{~d}^{-1}, 93.44 \mu \mathrm{g} \mathrm{g}^{-1} \mathrm{~d}^{-1}$ and $39.96 \mathrm{mg} \mathrm{g}^{-1} \mathrm{~d}^{-1}$, respectively, confirming that biochar not only can provide a favorable habitat but also sufficient nutrients for microbes to produce enzymes and biodegrade the contaminants. ${ }^{40}$ However, the enzymatic activities slightly decreased at 60 days and the possible cause of such change may be due to the partial decomposition of biochar and accumulation of residues of refractory components inhibiting the activity of microorganisms, leading to microbial exfoliation and even death.

\subsection{Microbial respiration and petroleum-degrading bacteria diversity}

Microbial basic respiration is an extensively used biological index of soil ecosystems that can reflect the utilization of TPHs by microorganisms. Previous studies have reported that $\mathrm{CO}_{2}$ production is an important parameter for the growth, metabolism and reproduction of microbes in contaminated soils. ${ }^{\mathbf{4 1 , 4 2}}$ The characterization of the petroleum-degrading bacteria diversity could indicate the variability of the microbe abundance during the soil remediation, and also access the condition of microbial degradation in petroleum hydrocarbon pollutant. As shown in Fig. 4, in the pre-stage, the microbial
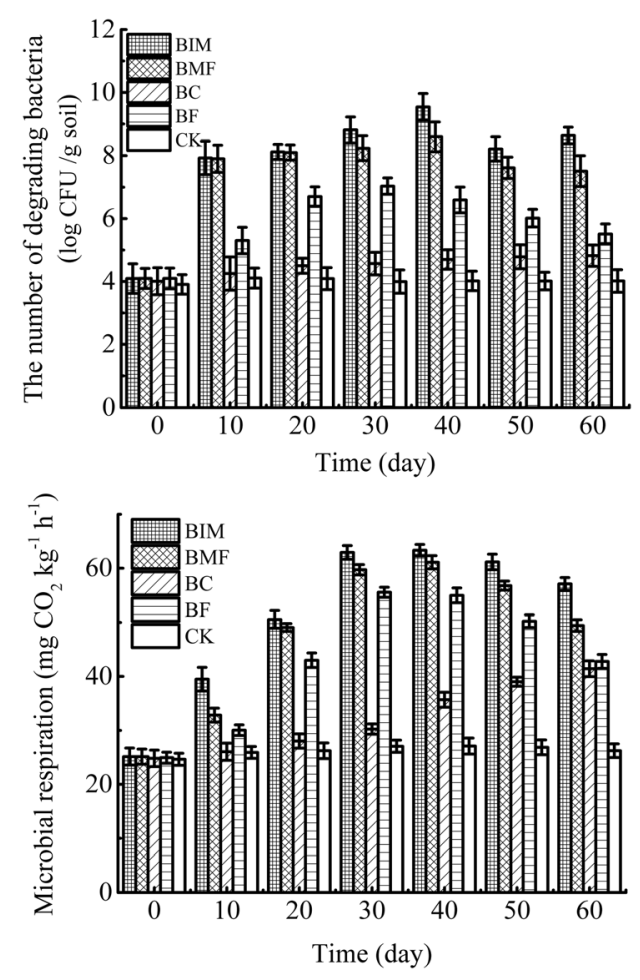

Fig. 4 Variation of TPH-degrading bacterial diversity and microbial basic respiration. respiration rate and TPHs-degrading bacteria diversity in the $\mathrm{BIM}, \mathrm{BMF}$, and BF treatments gradually increased, and then decreased after 40 days remediation, which were in good agreement with the enzymatic activities throughout the remediation process. This may occur in response to the abundant nutrients in the soil and the suitable living environment in the early restoration. After a short adaptation period, the number of exogenous degrading bacteria increased rapidly within 10 to 30 days. Correspondingly, the growth metabolism and respiratory intensity were significantly increased. At 40 days, due to the living environment of the microorganisms becoming worse with decreasing redox potential and nutrients such as C, N, P and the competition of indigenous microorganisms, the exogenous bacteria counts and microbial respiratory intensity were clearly decreased. However, generally, the addition of biochar could significantly increase the number and activity of microorganisms in petroleum-contaminated soil.

In the five pot experiments, the $\mathrm{CO}_{2}$ emission and bacteria quantity showed the trend of $\mathrm{BIM}>\mathrm{BMF}>\mathrm{BF}>\mathrm{BC}>\mathrm{CK}$. The two indicators in the BIM treatment achieved the optimum value and were $63.33 \mathrm{mg} \mathrm{CO}_{2} \mathrm{~kg}^{-1} \mathrm{~h}^{-1}$ and $9.5 \times 10^{10} \mathrm{CFU} \mathrm{g}^{-1}$ at 40 days. In the coexistence system of biochar and bacteria, the abundant pore structure and strong adsorption ability of biochar not only provided pathways for bacterial migration to strengthen bacterial growth and delay the decline period, but also improved the bioavailability of bacteria to pollutants. ${ }^{43}$ However, there was no decrease in the $\mathrm{BC}$ microcosm during the 60 days of treatment, indicating that the addition of biochar in the TPHs-contaminated soil had an obvious stimulatory effect on soil microbial respiration and organic $\mathrm{C}$ mineralization. ${ }^{44}$ In the control treatment, a slight increase occurred in the microbial respiration in the first 30 days, implying that a balanced fertilizer is also vital to the soil biodiversity and biodegradation of pollutants.

The redundancy analysis (RDA) can be used to illustrate the relationship between the TPHs removal efficiency and the soil physicochemical features. As shown in Fig. 5a, RDA1 explained $81.97 \%$ of the total variability, and RDA2 described $16.24 \%$ of the total variability. The soil enzymatic activities, bacteria counts and microbial respiration were close to each other and also showed a very close positive correlation with the TPHs removal rate, demonstrating that these higher values contributed to the TPHs remediation process. Nevertheless, soil $\mathrm{pH}$ and EC were negatively and insignificantly correlated with the TPHs removal efficiency, while the organic matter showed a significantly negative correlation. This might be due to the fact that organic carbon could evidently modify the soil properties as a carbon source ${ }^{45}$ and contribute to the bacterial degradation of petroleum hydrocarbons with sufficient nutrients.

Depending on the data generated in the study, a possible system mechanism of the free and immobilized-microbe is shown in Fig. 5b. Compared with the free bacteria, immobilized microorganisms can adsorb and enrich petroleum hydrocarbons through two mechanisms of surface adsorption and micropore volume filling. ${ }^{46}$ The extracellular enzymes secreted by microorganisms can not only adhere to the surface of the 
(a)

(b)
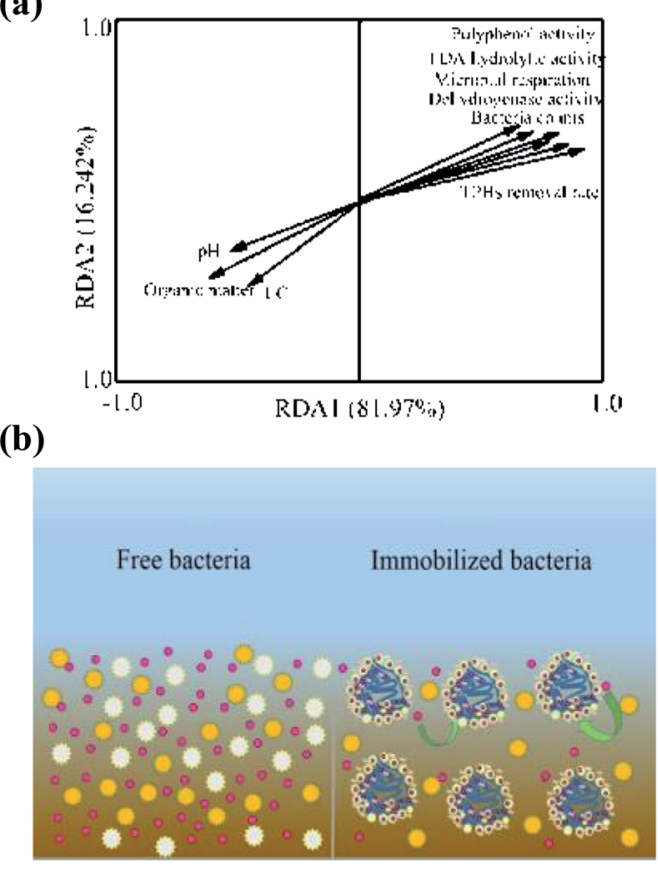

$*$ : Indigenous bacteria $\odot: \mathrm{TPH}$ : Petroleum-degrading : Immobilized bacteria

Fig. 5 (a) Redundancy analysis (RDA) of soil and TPHs removal efficiency; (b) the free and immobilized-microbe system mechanism.

immobilized materials, but also enter the pore to accelerate the degradation of pollutants. Furthermore, the immobilized bacteria can enhance oxygen flow, increase soil porosity and permeability, and provide a favorable buffer system for microorganisms, making the exogenous degrading bacteria become the dominant bacteria. In addition, the microenvironment is also an important acclimation site for indigenous microorganisms, which can improve its density and activity stability to achieve a synergistic effect of the indigenous and exogenous bacteria.

It is not necessary to consider the recovery of immobilized carrier material in soil remediation because it will become a part of the soil system with time, but the requirements for nutrients, non-toxic and harmless properties of the carrier materials become more stringent. Accordingly, we selected a biochar prepared by an agricultural waste as the immobilization carrier material with a simple and efficient adsorption method. The immobilized microorganisms not only have high efficiency of TPHs degradation, but do not have a toxic effect on the soil and microorganisms, achieving dual functions of the reuse of wastes and environmental rehabilitation.

\section{Conclusions}

On the basis of the present study, spent mushroom substrate biochar was used to immobilize petroleum hydrocarbon degrading bacteria by a simple and efficient adsorption method and then applied to remediate TPHs-contaminated soil. After 60 days of bioremediation, the application of immobilized bacteria on biochar had resulted in the largest decline of petroleum and $n$-alkane with $\mathrm{C}_{12-18}$. The TPHs removal efficiencies were 58.08 , $45.31,29.85,38.63$ and $8.69 \%$ in the BIM, BMF, BC, BF and control treatments, respectively. The TPHs in the immobilized treatment method showed the shortest half-life and highest biodegradation efficiency, in which the immobilized microbe played a significant role. Additionally, organic matter, enzymatic activities and microbial diversity analysis indicated that biochar not only fertilized soil and regulated physicochemical properties of the soil, it provided a beneficial buffer environment for the indigenous and exogenous bacteria and satisfied the need for the bacterial metabolism of petroleum hydrocarbons, achieving the synergistic effect of biostimulation and bioaugmentation. The current study highlights the potential of immobilized degrading bacteria on biochar in TPHs dissipation to broaden its potential for greater remediation effectiveness; however, the long-term impact of biochar and bacteria addition will enhance the degradation ability needs further study.

\section{Conflicts of interest}

There are no conflicts to declare.

\section{Acknowledgements}

This study was supported by the Basic Research Project of China Petroleum Science and Technology Innovation Fund (Grant: 2017D-5007-0601) and the Natural Science Foundation of Shandong Province (Grant: ZR2014BM023). The authors especially would like to thank Wenfei Xu, Rui Xin and Hongyu Jia for references consulting and checking, mechanism system constructing and SEM images analyses, respectively.

\section{Notes and references}

1 M. Wu, W. A. Dick, W. Li, X. Wang, Q. Yang, T. Wang, L. Xu, M. Zhang and L. Chen, Int. Biodeterior. Biodegrad., 2016, 107, 158-164.

2 S. T. Forrester, L. J. Janik, M. J. McLaughlin, J. M. SorianoDisla, R. Stewart and B. Dearman, Soil Sci. Soc. Am. J., 2013, 77, 450-460.

3 M. A. Lominchar, D. Lorenzo, A. Romero and A. Santos, J. Chem. Technol. Biotechnol., 2018, 93, 1270-1278.

4 M. Rahbari-Sisakht, A. Pouranfard, P. Darvishi and A. F. Ismail, J. Chem. Technol. Biotechnol., 2017, 92, 10531064.

5 A. Ebadi, N. A. Khoshkholgh Sima, M. Olamaee, M. Hashemi and R. Ghorbani Nasrabadi, J. Environ. Manage., 2018, 219, 260-268.

6 D. Borah and R. N. S. Yadav, Egypt. J. Pet., 2017, 26, 181-188.

7 H. Cui, X. Yang, L. Xu, Y. Fan, Q. Yi, R. Li and J. Zhou, RSC Adv., 2017, 7, 45869-45877.

8 H. Su, S. Mi, X. Peng and Y. Han, RSC Adv., 2019, 9, 1893018940. 
9 I. P. Thompson, C. J. van der Gast, L. Ciric and A. C. Singer, Environ. Microbiol., 2005, 7, 909-915.

10 J. Xue, Y. Wu, K. Shi, X. Xiao, Y. Gao, L. Li and Y. Qiao, Bioresour. Technol., 2019, 280, 88-94.

11 K. Shi, Z. Liu, H. Xu, J. Xue, Y. Liu, Y. Wu, X. Xiao, Y. Gao and B. Liu, Pet. Sci. Technol., 2018, 36, 1361-1367.

12 X. Wang, J. Zheng, Z. Han and H. Chen, J. Chem. Technol. Biotechnol., 2019, 94, 1904-1912.

13 A. D. Igalavithana, Y. S. Ok, A. R. A. Usman, M. I. Al-Wabel, P. Oleszczuk and S. S. Lee, The Effects of Biochar Amendment on Soil Fertility, Soil Science Society of America, 2016, pp. 123-144.

14 G. Cimò, J. Kucerik, A. E. Berns, G. E. Schaumann, G. Alonzo and P. Conte, J. Agric. Food Chem., 2014, 62, 1912-1918.

15 X. Wang, W. Zhou, G. Liang, D. Song and X. Zhang, Sci. Total Environ., 2015, 538, 137-144.

16 D. Mohan, K. Abhishek, A. Sarswat, M. Patel, P. Singh and C. U. Pittman, RSC Adv., 2018, 8, 508-520.

17 G. Zhang, X. Guo, Y. Zhu, X. Liu, Z. Han, K. Sun, L. Ji, Q. He and L. Han, Geoderma, 2018, 328, 100-108.

18 G. Zhang, Q. Zhang, K. Sun, X. Liu, W. Zheng and Y. Zhao, Environ. Pollut., 2011, 159, 2594-2601.

19 X. Li, X. Wang, L. Wan, Y. Zhang, N. Li, D. Li and Q. Zhou, J. Chem. Technol. Biotechnol., 2016, 91, 267-275.

20 H. Zhang, J. Tang, L. Wang, J. Liu, R. G. Gurav and K. Sun, J. Environ. Sci., 2016, 47, 7-13.

21 K. Heil and U. Schmidhalter, Comput. Geosci., 2012, 39, 98110.

22 J. Karcz, T. Bernas, A. Nowak, E. Talik and A. Woznica, Scanning, 2012, 34, 26-36.

23 W. Chang, M. Dyen, L. Spagnuolo, P. Simon, L. Whyte and S. Ghoshal, Chemosphere, 2010, 80, 319-326.

24 M. Rostami and S. Rostami, Chemosphere, 2019, 232, 70-75.

25 M. Safari, F. N. Alishah, H. K. Dolatabad, U. Ndu, C. P. Schulthess and A. Sorooshzadeh, J. Plant Nutr. Soil Sci., 2019, 182, 463-476.

26 W. Liu, W. Xu, J. Hong and S. Wan, Geoderma, 2010, 158, 259-267.

27 F. Meng and J. Chi, J. Hazard. Mater., 2017, 324, 391-397.

28 W. Zhang, X. Ren, J. He, Q. Zhang, C. Qiu and B. Fan, J. Hazard. Mater., 2019, 377, 113-123.
29 J. Liu, M. Yang, Y. Wang, L. Qu and G. Zhong, J. Hazard. Mater., 2019, 376, 29-36.

30 N. Ni, F. Wang, Y. Song, R. Shi, M. Jia, Y. Bian and X. Jiang, RSC Adv., 2017, 7, 41444-41451.

31 I. Villaescusa, N. Fiol, J. Poch, A. Bianchi and C. Bazzicalupi, Desalination, 2011, 270, 135-142.

32 I. Villaescusa, N. Fiol, J. Poch, A. Bianchi and C. Bazzicalupi, Desalination, 2011, 270, 135-142.

33 J. Huang, Q. Li, Y. Bao and C. Wu, Colloid Polym. Sci., 2009, 287, 37-43.

34 He. Yingying and X. Wang, Colloids Surf., A, 2011, 379, 93101.

35 R. C. Sims and J. L. Sims, Landfarming of Petroleum Contaminated Soils, Soil Science Society of America, 1999, pp. 767-781.

36 M. W. Ullah, Z. Shi, X. Shi, D. Zeng, S. Li and G. Yang, ACS Sustainable Chem. Eng., 2017, 5, 11163-11175.

37 T. Sakata, T. Kojima, M. Fujieda, M. Takahashi and T. Michibata, Proc. Nutr. Soc., 2003, 62, 73-80.

38 R. J. Haynes and M. H. Graham, S. Afr. J. Plant Soil, 2004, 21, 330-344.

39 W. Dong, X. Zhang, X. Dai, X. Fu, F. Yang, X. Liu, X. Sun, X. Wen and S. Schaeffer, Appl. Soil Ecol., 2014, 84, 140-147.

40 J. Jiang, M. Yuan, R. Xu and D. L. Bish, Soil Tillage Res., 2015, 146, 139-147.

41 X. Domene, A. Enders, K. Hanley and J. Lehmann, Sci. Total Environ., 2015, 512-513, 552-561.

42 M. Wang, B. Zhang, G. Li, T. Wu and D. Sun, RSC Adv., 2019, 9, 242-2411.

43 S. O. Nyawade, N. N. Karanja, C. K. K. Gachene, H. I. Gitari, E. Schulte-Geldermann and M. L. Parker, Appl. Soil Ecol., 2019, 142, 123-135.

44 Y. Xu, B. Seshadri, B. Sarkar, H. Wang, C. Rumpel, D. Sparks, M. Farrell, T. Hall, X. Yang and N. Bolan, Sci. Total Environ., 2018, 621, 148-159.

45 Y. E. Navarro-Noya, S. Gómez-Acata, N. Montoya-Ciriaco, A. Rojas-Valdez, M. C. Suárez-Arriaga, C. ValenzuelaEncinas, N. Jiménez-Bueno, N. Verhulst, B. Govaerts and L. Dendooven, Soil Biol. Biochem., 2013, 65, 86-95.

46 T. Brányik, D. P. Silva, A. A. Vicente, R. Lehnert, J. B. A. E. Silva, P. Dostálek and J. A. Teixeira, J. Ind. Microbiol. Biotechnol., 2006, 33, 1010-1018. 